\title{
BAT-BORNE RABIES IN LATIN AMERICA
}

\begin{abstract}
SUMMARY
The situation of rabies in America is complex: rabies in dogs has decreased dramatically, but bats are increasingly recognized as natural reservoirs of other rabies variants. Here, bat species known to be rabies-positive with different antigenic variants, are summarized in relation to bat conservation status across Latin America. Rabies virus is widespread in Latin American bat species, $22.5 \%{ }^{75}$ of bat species have been confirmed as rabies-positive. Most bat species found rabies positive are classified by the International Union for Conservation of Nature as "Least Concern". According to diet type, insectivorous bats had the most species known as rabies reservoirs, while in proportion hematophagous bats were the most important. Research at coarse spatial scales must strive to understand rabies ecology; basic information on distribution and population dynamics of many Latin American and Caribbean bat species is needed; and detailed information on effects of landscape change in driving bat-borne rabies outbreaks remains unassessed. Finally, integrated approaches including public health, ecology, and conservation biology are needed to understand and prevent emergent diseases in bats.
\end{abstract}

KEYWORDS: Rabies virus; Bats; Geographic distribution; Biodiversity.

\section{INTRODUCTION}

Bats offer diverse cultural and economic contributions to human situations, such as ecotourism, vector control, guano, medicinal products, and religious significance, among others ${ }^{42}$. Bat diets include insects, fruits, leaves, flowers, nectar, pollen, fish, other vertebrates, and blood $^{41}$. Insectivorous bats consume large quantities of insects and other arthropods under natural conditions or related to anthropogenic activities, controlling important agricultural pests and potential disease vectors ${ }^{39,40,42}$. Nectarivorous bats help to maintain diversity in forests through dispersal of seeds and pollen, essential to many plant species with high economic, biological, and cultural value ${ }^{42}$. With around 1230 species, bats are the second most diverse mammal order (after rodents), with an impressively broad ecological and geographic distribution ${ }^{41,42}$.

Rabies virus is the most important virus in the genus Lyssavirus because, from a global perspective, its distribution, human cases $(>55,000$ deaths per year), wide range of potential reservoirs, and veterinary and economic cost implications make it the most important viral zoonosis ${ }^{73}$. Rabies transmission cycles in wild and domestic carnivores have existed almost worldwide, whereas bat-mediated transmission of rabies virus occurs only in North, Central, and South America; in Europe, Africa, Asia, and Australia, bats are reservoirs of different Lyssavirus species ${ }^{44,55,72,87}$. In America, bats now constitute the principal rabies reservoir ${ }^{73,74}$, rabies is thought to have occurred in tropical America since pre-Hispanic times, being transmitted predominantly by hematophagous vampire bats ${ }^{3}$, although recent phylogenetic reconstructions suggest that rabies virus in the Americas is unlikely to have originated from vampire bats ${ }^{46}$. The first scientific report of rabies in America was by CARINI (1911), in São Paulo, Brazil ${ }^{7}$. Advances in diagnostic techniques have now contributed to an understanding of bat-rabies dynamics ${ }^{83}$.

In Latin America, human rabies cases have decreased in recent decades ${ }^{57-61}$, with mortality rates estimated at $0.01-0.60$ per 100,000 individuals $^{29,37}$. Between 1993 and 2002, annual incidence of human rabies in Latin America was 105 cases, ranging 0.00-0.09 per 100,000 individuals in South America, 0.00-0.10 in Central America, and 0.000.06 in the Caribbean ${ }^{9}$ Brazil, Peru, Mexico, and Colombia are the countries with most human cases of rabies in the region ${ }^{80}$, although on a per capita basis Peru and Colombia dominate.

In fact, by 2013, human and canine rabies rates in Latin America had decreased by $95 \%$ compared to previous years (Fig. 1). Epidemiological surveillance is considered to have been essential for control of rabies in Latin America ${ }^{79}$. However, while reports of rabid dogs in Latin America have declined, the number of bat rabies cases appears stable (Fig. 1). Although further data compilation is needed for a clearer picture of this phenomenon, in Latin America, data on rabies are woefully limited and biased by uneven surveillance effort.

Antigenic variants of rabies (AgV) can be identified by monoclonal antibody techniques ${ }^{29}$. Dog rabies (variants 1 and 2) has decreased

(1) Facultad de Ecología y Recursos Naturales, Universidad Andres Bello, Av. República 440, Santiago Centro, Chile.

(2) Center for Global Health and Translational Science, State University of New York Upstate Medical University, Syracuse, New York, USA.

(3) Biodiversity Institute, University of Kansas, Lawrence 66045, USA.

(4) Sección Rabia, Subdepartamento de Virología, Instituto de Salud Pública de Chile, Av. Marathon 1000, Nuñoa, Santiago, Chile.

Correspondence to: Gonzalo Medina-Vogel. E-mail: gmedina@unab.cl 


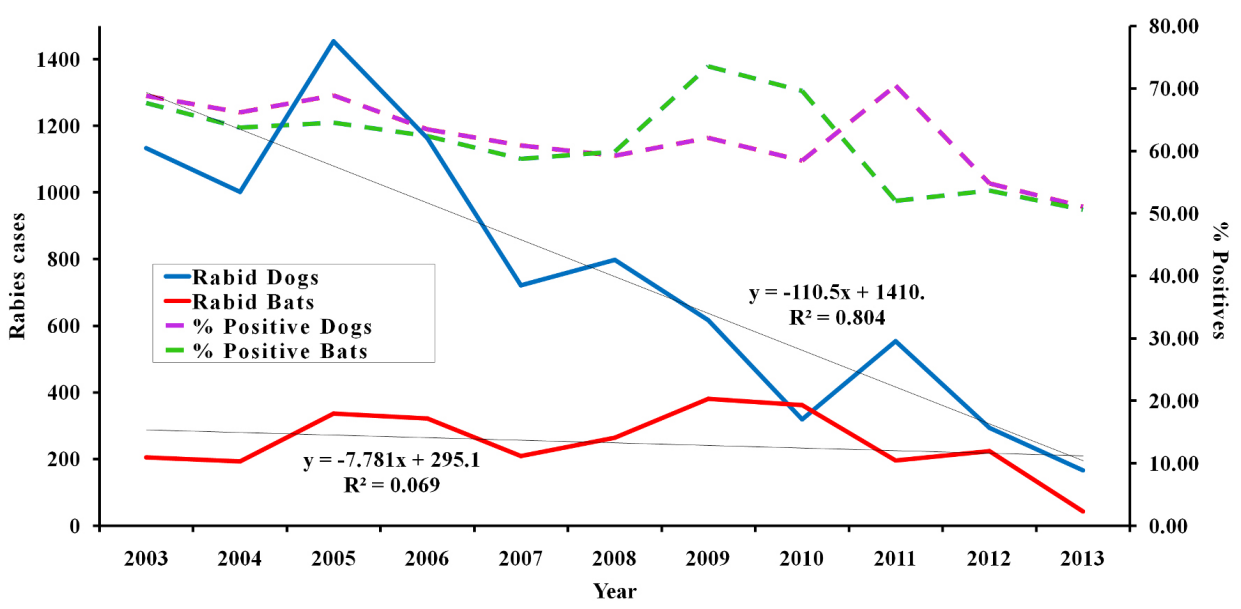

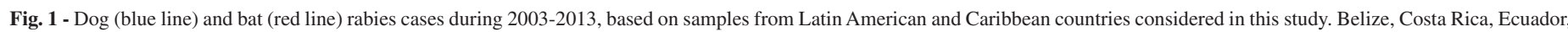

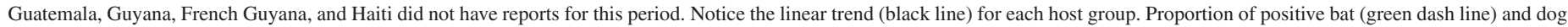
samples (purple dash line) is shown. Source: SIEPI-PANAFTOSA/PAHO-WHO, data available on http://siepi.panaftosa.org.br/

dramatically (Fig. 1), and now occurs only in circumscribed areas of Latin America. Hence, according to current epidemiological reports, bats now constitute the principal reservoir in Latin America ${ }^{73,74}$. Crossspecies spillover is well appreciated in bat-borne rabies ${ }^{19}$. Since 1975, at least 500 bat-associated cases of human rabies have been reported from across Latin America ${ }^{2}$. In 2004, the Regional Program for the Elimination of Rabies of the Pan American Health Organization (PAHO) reported for the first time more human cases of rabies derived from wild animals (bats, other small mammals) than from dogs ${ }^{78}$ : for example, in 2005, 13 cases of human rabies derived from dogs were reported, compared with 60 human cases derived from bats ${ }^{80}$. Indeed, even in Latin American countries considered "dog rabies free," human cases caused by bats have been reported ${ }^{4,21}$.

Both vampire and non-vampire bats have been involved in these events $^{4,21}$. Hence, after vampire bats, insectivorous bats have assumed a greater role as sources of the virus in Latin America ${ }^{10,26,38,75,78,90}$. In spite of the significant economic, ecological, and cultural stigmas and fears associated with this disease ${ }^{9}$, rabies surveillance in bats is limited in developing countries ${ }^{44}$. Consequently, the aim of this article is to review rabies occurrence in bats, evaluate geographic patterns in species richness of potential bat rabies reservoirs, and summarize knowledge of antigenic variants, ecology, food habits, and conservation status in key bat species. This article aims to characterize potential bat rabies reservoirs and guide new steps in research.

\section{METHODS}

For information on bat species (geographic distribution, diet, conservation status), data from the current, online IUCN database (www.iucn.org; accessed 13 Jan 2013) were used. To identify potential bat rabies reservoirs, summaries were made of bat species reported rabies-positive by country (i.e., Argentina, Belize, Bolivia, Brazil, Chile, Colombia, Costa Rica, Cuba, Dominican Republic, Ecuador, El Salvador, Guatemala, French Guyana, Guyana, Haiti, Honduras, Mexico, Nicaragua, Panama, Paraguay, Peru, Suriname, Trinidad and Tobago, Uruguay, and Venezuela). First, the Web of Science was searched for articles related to "bat rabies" in Latin American countries between 1953 and 2012 in English and Spanish, a number of articles from this search were used as search effort in posterior analysis. Because several articles from Latin American journals were not available via Web of Science, Google Scholar was searched for articles, theses, and official sources available online using the same criteria. Publications including rabies diagnosis based on histopathology, direct fluorescent antibody tests, or molecular techniques were included. When multiple manuscripts source the same bat species or antigenic variants from the same country, only the older such reference was cited (Table 1). To date, the most valuable compilation of rabies-positive bat species in Latin America was published by CONSTANTINE (2009), so part of this article's analysis is based on his data. For preliminary bat distributional information, vector-format based maps (shapefiles) from IUCN ${ }^{36}$ were used; maps were handled using ArcGIS 9.3 (ESRI). Chisquare tests were used to evaluate associations $(\alpha=0.05)$ between the response variable (i.e., number of rabies-positive species) and factors such as bat family, diet, and conservation status. Linear regressions were conducted to evaluate association between bat species (richness) with rabies-positive species and the number of manuscripts from the Web of Science (i.e., research effort) by country and rabies antigenic variants with bat species rabies positive by country. Statistical analyses were carried out in $\mathrm{R}^{71}$.

\section{RESULTS}

Bat species richness patterns: In all, 333 bat species were documented from 24 Latin American and Caribbean countries ${ }^{36}$. The countries with the highest species richness were Colombia (172 species), Brazil (155 species), and Venezuela (152 species; Fig. 2). Fifty-two species were endemic to single countries: Mexico had 17, and Brazil and Peru had nine each. None of these single-country endemic species were reported as rabies-positive. The number of species by family was Phyllostomidae (168 species), Vespertilionidae (82 species), Molossidae (38 species), Emballonuridae (21 species), Mormoopidae (nine species), Natalidae (seven species), Thyropteridae (four species), and Noctilionidae and Furipteridae (two species each). 
Table 1.

Bat species known to be rabies-positive in Latin America and the Caribbean

\begin{tabular}{|c|c|c|c|c|c|c|}
\hline Insectivorous & Frugivorous & Nectarivorous & Omnivorous & Carnivorous & $\begin{array}{c}\text { Hema- } \\
\text { tophagous }\end{array}$ & $\mathrm{AgV}$ \\
\hline \multicolumn{7}{|l|}{ Argentina } \\
\hline $\begin{array}{l}\text { Eumops auripendulus }{ }^{\dagger 12} \\
\text { Eumops patagonicus }{ }^{\dagger 10} \\
\text { Histiotus montanus } * 10 \\
\text { Myotis sp } * 10 \\
\text { Myotis nigricans } * 10 \\
\text { Tadarida brasiliensis } \\
\text { Eptesicus furinalis } * 69 \\
\text { Molossus molossus }{ }^{\dagger 69} \\
\text { Lasiurus blossevillii } * 69 \\
\text { Lasiurus cinereus }^{* 33,69} \\
\text { Lasiurus ega }^{* 69}\end{array}$ & Artibeus lituratus ${ }^{\bullet 15}$ & & & & $\begin{array}{l}\text { Desmodus } \\
\text { rotundus }^{* 69}\end{array}$ & $\begin{array}{c}V 3^{69} \\
V 4^{33,69} \\
V 6^{33,69} \\
E^{69} \\
H^{69} \\
M^{69}\end{array}$ \\
\hline \multicolumn{7}{|l|}{ Belize } \\
\hline $\begin{array}{l}\text { Myotis fortidens } * 12 \\
\text { Myotis nigricans } * 12 \\
\text { Molossus molossus } \\
\text { Molossus sinaloae } \\
\text { †12 }\end{array}$ & $\begin{array}{c}\text { Artibeus jamaicensis }^{\cdot 12} \\
\text { Artibeus lituratus }^{\cdot 12}\end{array}$ & & $\begin{array}{l}\text { Phyllostomus } \\
\text { discolor }^{-12}\end{array}$ & & $\begin{array}{l}\text { Desmodus } \\
\text { rotundus }^{\cdot 12}\end{array}$ & - \\
\hline \multicolumn{7}{|l|}{$\underline{\text { Bolivia }}$} \\
\hline & $\begin{array}{l}\text { Artibeus jamaicensis }{ }^{\cdot 12} \\
\text { Artibeus lituratus }^{\cdot 12}\end{array}$ & & & & $\begin{array}{l}\text { Desmodus } \\
\text { rotundus }{ }^{\cdot 12}\end{array}$ & $\begin{array}{l}V 3^{22} \\
V 5^{22}\end{array}$ \\
\hline Brazil & & & & & & \\
\hline
\end{tabular}

Cynomops abrasus ${ }^{\dagger 82}$

Cynomops planirostris ${ }^{\dagger 82}$

Eptesicus diminutus $* 82$

Eptesicus furinalis $* 82$

Eptesicus brasiliensis $* 82$

Eumops $_{\text {glaucinus }}{ }^{\dagger 82}$

Eumops perotis ${ }^{\dagger 82}$

Eumops auripendulus ${ }^{\dagger 82}$

Histiotus velatus $* 82$

Lasiurus blossevillii *82

Lasiurus cinereus $* 82$

Lasiurus ega ${ }^{* 82}$

Lasiurus egregius $* 82$

Lonchorhina aurita $^{\cdot 82}$

Lophostoma brasiliense $^{\cdot 82}$

Micronycteris megalotis ${ }^{82}$

Molossus molossus ${ }^{\dagger 82}$

Molossops neglectus ${ }^{\dagger 82}$

Molossus rufus ${ }^{\dagger 82}$

Molossus sinaloae ${ }^{\dagger 12}$

Myotis albescens $* 82$

Myotis levis $* 82$

Myotis nigricans $* 82$

Myotis riparius $* 82$

Nyctinomops laticaudatus ${ }^{\dagger 82}$

Nyctinomops macrotis ${ }^{\dagger 82}$

Promops nasutus ${ }^{\dagger 12}$

Tadarida brasiliensis ${ }^{\dagger 82}$

\section{Colombia}

Eptesicus brasiliensis $* 65$

Molossus molossus ${ }^{\dagger 65}$

Carollia perspicillata ${ }^{\cdot 53}$
Artibeus jamaicensis ${ }^{\cdot 12}$

Artibeus lituratus ${ }^{\circ 2}$

Artibeus planirostris ${ }^{82}$

Carollia perspicillata ${ }^{82}$

Platyrrhinus lineatus ${ }^{\cdot 82}$

Sturnira lilium ${ }^{\cdot 12}$

Uroderma bilobatum $^{\cdot 82}$

Vampyrodes caraccioli $^{\cdot 12}$
$V 3^{26,35}$

$V 4^{26,35}$

Desmodus $\quad V 5^{26}$
Anoura caudifer ${ }^{\circ 2}$

Anoura geoffroyi ${ }^{\bullet 2}$

Glossophaga soricina ${ }^{* 82}$

Phyllostomus hastatus $^{82}$
Chrotopterus auritus $^{\cdot 82}$

Trachops

cirrhosus $^{\circ 2}$ rotundus ${ }^{\circ 2}$

$V 6^{26,35}$

$E^{26}$

$H^{26}$

youngi ${ }^{\bullet 82}$

Diphylla

ecaudata $^{\circ 2}$

$E u^{26}$

$N^{26}$

$L b^{26}$

Desmodus

rotundus ${ }^{\circ 6}$ 
Table 1

Bat species known to be rabies-positive in Latin America and the Caribbean (cont.)

\begin{tabular}{|c|c|c|c|c|}
\hline Insectivorous & Nectarivorous & Omnivorous Carnivorous & $\begin{array}{c}\text { Hema- } \\
\text { tophagous }\end{array}$ & $\mathrm{AgV}$ \\
\hline \multicolumn{5}{|l|}{ Costa Rica } \\
\hline & & & $\begin{array}{l}\text { Desmodus } \\
\text { rotundus }\end{array}$ & $V 3^{4}$ \\
\hline \multicolumn{5}{|l|}{ Cuba } \\
\hline \multicolumn{5}{|l|}{$\begin{array}{l}\text { Eptesicus fuscus }{ }^{* 12} \\
\text { Eumops glaucinus }{ }^{\dagger 54}\end{array}$} \\
\hline \multicolumn{5}{|l|}{ Chile } \\
\hline $\begin{array}{l}\text { Histiotus macrotus } * 23,24 \\
\text { Histiotus montanus } * 23,24 \\
\text { Lasiurus borealis } * 23,24 \\
\text { Lasiurus cinereus } * 23,24 \\
\text { Myotis chiloensis } * 23,24 \\
\text { Tadarida brasiliensis }{ }^{\dagger 23,24} \\
\end{array}$ & & & 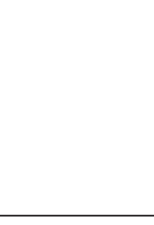 & $\begin{array}{l}M^{20,23,24,92} \\
V 4^{20,23,24,92} \\
V 6^{20,23,24,92} \\
H^{20,23,24,92}\end{array}$ \\
\hline \multicolumn{5}{|l|}{$\underline{\text { Ecuador }}$} \\
\hline 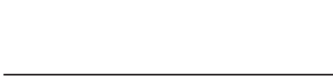 & & & $\begin{array}{l}\text { Desmodus } \\
\text { rotundus }\end{array}$ & $V 3^{27}$ \\
\hline \multicolumn{5}{|l|}{ El Salvador } \\
\hline & & & $\begin{array}{l}\text { Desmodus } \\
\text { rotundus }^{\cdot 12}\end{array}$ & - \\
\hline \multicolumn{5}{|l|}{ Guatemala } \\
\hline $\begin{array}{l}\text { Molossus sinaloae } e^{\dagger 12} \\
\text { Myotis fortidens } * 12\end{array}$ & Artibeus lituratus ${ }^{\cdot 12}$ & $\begin{array}{l}\text { Phyllostomus } \\
\text { discolor }^{-12}\end{array}$ & $\begin{array}{l}\text { Desmodus } \\
\text { rotundus }^{\cdot 12}\end{array}$ & - \\
\hline \multicolumn{5}{|l|}{ French Guyana } \\
\hline & & & $\begin{array}{l}\text { Desmodus } \\
\text { rotundus }^{\cdot 52}\end{array}$ & $V 3^{52}$ \\
\hline \multicolumn{5}{|l|}{ Honduras } \\
\hline Molossus sinaloae ${ }^{\dagger 1}$ & & & $\begin{array}{l}\text { Desmodus } \\
\text { rotundus }^{\cdot 13}\end{array}$ & - \\
\hline Mexico & & & & \\
\hline
\end{tabular}

Antrozous pallidus $* 12$

Eptesicus fuscus $* 12$

Lasiurus blossevillii ${ }^{* 12}$

Lasiurus cinereus $* 12$

Lasiurus ega*12

Lasiurus intermedius $* 12$

Lasiurus seminolus ${ }^{* 12}$

Macrotus waterhousii ${ }^{12}$

Molossus rufus ${ }^{\dagger 12}$

Mormoops megalophylla ${ }^{£ 1}$

Myotis velifer ${ }^{* 12}$

Nyctinomops laticaudatus ${ }^{\dagger 12}$

Nyctinomops macrotis ${ }^{\dagger 12}$

Pteronotus personatus ${ }^{£ 12}$

Pipistrellus subflavus*12

Pteronotus parnellii ${ }^{£ 12}$

Pteronotus davyi $i^{\ddagger 12}$

Rhogeessa parvula*1

Rhogeessa tumida*12

Tadarida brasiliensi ${ }^{\dagger 90}$

\section{Nicaragua}

Artibeus jamaicensis s0 $^{\cdot 90}$ Artibeus lituratus ${ }^{\circ}$

Carollia subrufa ${ }^{\cdot 12}$
Glossophaga soricina ${ }^{-1}$

Leptonycteris nivalis ${ }^{\circ 1}$

Leptonycteris yerbabuenae $^{\cdot 12}$
Desmodus rotundus ${ }^{\circ 0}$
Phyllostomus discolor ${ }^{\cdot 12}$
$V 3^{17,43,50,89}$

$V 4^{17,43,50,89}$

$V 5^{17,43,50,89}$

$V 6^{17,43,50,89}$

$V 8^{17,43,50,89}$

$V 9^{17,43,50,89}$

VI 17,43,50,89 
Table 1.

Bat species known to be rabies-positive in Latin America and the Caribbean (cont.)

\begin{tabular}{|c|c|c|c|c|c|c|}
\hline Insectivorous & Frugivorous & Nectarivorous & Omnivorous & Carnivorous & $\begin{array}{c}\text { Hema- } \\
\text { tophagous }\end{array}$ & $\mathrm{AgV}$ \\
\hline \multicolumn{7}{|l|}{ Panama } \\
\hline $\begin{array}{l}\text { Cynomops planirostris }^{\dagger 1} \\
\text { Micronycteris megalotis } \text { me }^{\cdot 12} \\
\text { Molossus coibensis } \\
\text { Molossus currentium } \\
\text { Molossus molossus } \\
\text { Myotis nigricans }^{\dagger 12} \\
\end{array}$ & $\begin{array}{l}\text { Artibeus jamaicensis } \text { ja }^{\cdot 1} \\
\text { Uroderma bilobatum }^{\cdot 1}\end{array}$ & & & Noctilio sp. $\$^{\ddagger 12}$ & & - \\
\hline \multicolumn{7}{|l|}{ Paraguay } \\
\hline $\begin{array}{l}\text { Lasiurus ega }{ }^{* 81} \\
\text { Tadarida brasiliensis }{ }^{\dagger 8}\end{array}$ & Artibeus jamaicensis ${ }^{\bullet}$ & & & & $\begin{array}{l}\text { Desmodus } \\
\text { rotundus } \\
12\end{array}$ & $\begin{array}{l}V 6^{81} \\
V 3^{64}\end{array}$ \\
\hline \multicolumn{7}{|l|}{ Peru } \\
\hline $\begin{array}{l}\text { Myotis nigricans }{ }^{* 12} \\
\text { Micronycteris megalotis }{ }^{\cdot 12} \\
\text { Molossus molossus }\end{array}$ & 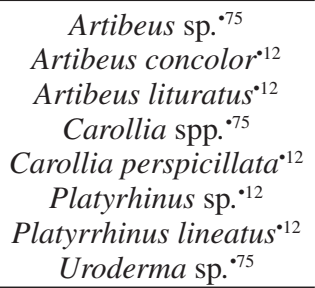 & Glossophaga soricina ${ }^{\cdot 12}$ & $\begin{array}{l}\text { Phyllostomus } \\
\text { hastatus }^{\bullet 12} \\
\text { Phyllostomus } \\
\text { elongatus }^{\cdot 12}\end{array}$ & & $\begin{array}{l}\text { Desmodus } \\
\text { rotundus }\end{array}$ & $V 3^{91}$ \\
\hline
\end{tabular}

\section{Dominican Republic}

Tadarida brasiliensis ${ }^{\dagger 62}$

\section{Trinidad and Tobago}

Diclidurus albus ${ }^{31}$

Molossus molossus ${ }^{\dagger 31}$

Pteronotus davyi $i^{\ddagger 31}$

Pteronotus parnellii ${ }^{£ 12}$

\section{Uruguay}

\section{Lasiurus cinereus ${ }^{* 69}$}

Lasiurus ega ${ }^{* 69}$

Molossus molossus ${ }^{\dagger 32}$

Myotis spp. *69

Tadarida brasiliensis ${ }^{\dagger 69}$

\section{Venezuela}

Molossus rufus ${ }^{\dagger 16}$

Artibeus jamaicensis $^{\cdot 31}$
Artibeus lituratus $^{31}$
Carollia perspicillata $^{\cdot 31}$

Artibeus jamaicensis ${ }^{\cdot 31}$

Carollia perspicillata ${ }^{* 31}$
Desmodus

rotundus ${ }^{\circ 31}$

Diaemus

youngi ${ }^{\cdot 31}$
Desmodus $\quad V 4^{69}$

rotundus ${ }^{69} \quad V 3^{32}$

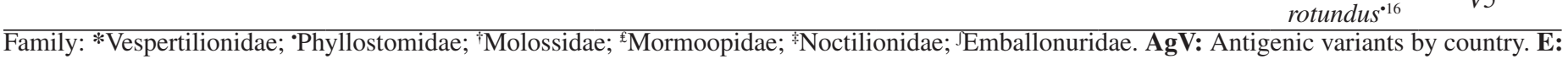
Antigenic variant for Eptesicus spp.; Eu: Eumops; H: Antigenic variant for Histiotus spp.; Lb: Lasiurus borealis; M: Antigenic variant for Myotis spp.; N: Nyctinomops; V3, V5, V8, V11: Antigenic variant for D. rotundus; V4, V9: T. brasiliensis; V6: Lasiurus spp.

The largest host geographic distributions were for Lasiurus cinereus $\left(39.2 \times 10^{6} \mathrm{~km}^{2}\right)$, L. blossevillii $\left(22.6 \times 10^{6} \mathrm{~km}^{2}\right)$, and Tadarida brasiliensis $\left(17.7 \times 10^{6} \mathrm{~km}^{2}\right)$, all insectivorous. Considering other diets, the species with the largest distributions were Sturnira lilium 16.4 x $10^{6}$ $\mathrm{km}^{2}$ (frugivorous), Glossophaga soricina $15.7 \times 10^{6} \mathrm{~km}^{2}$ (nectarivorous), Noctilio leporinus $15.5 \times 10^{6} \mathrm{~km}^{2}$ (carnivorous), and Desmodus rotundus $19.3 \times 10^{6} \mathrm{~km}^{2}$ (hematophagous).

In all, 75 (22.5\%) Latin American bat species have been confirmed as rabies-positive, at least as incidental records (see Table 1). The countries with more bat species rabies-positive reports were Brazil (43), Mexico (31), and Argentina (13; Fig. 3). Only Guyana, Suriname, and Haiti are countries lacking bat-rabies records. It was found that the number of rabies-positive species is not related to number of bat species (richness) reported per country $\left(r^{2}=0.1238, \mathrm{df}=24, p=0.078\right)$. From the first search of articles (i.e., Web of Science), no association was found ( $r=0.2768$, $\mathrm{df}=7, P=$ 0.4708 ) between the number of bat species and publications by country; for example, Chile, with the fewest bat species, has nine publications about bat-borne rabies while Colombia with the highest number of bat species has only four publications. An association was found between number of 


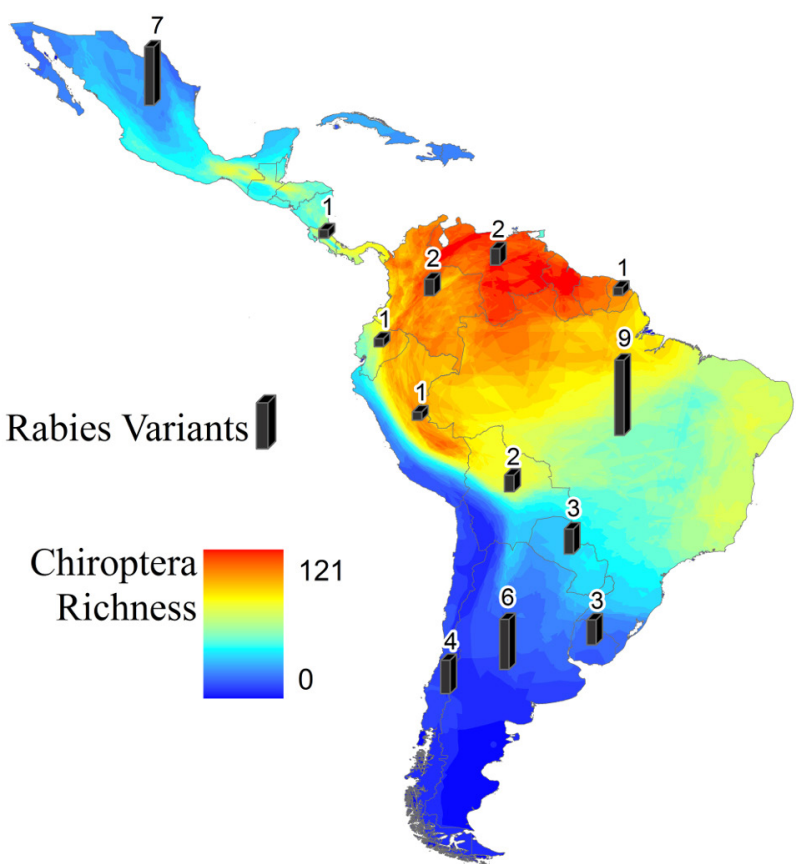

Fig. 2 - Bat richness showing the number of bat species (rabies positive or not) present in Latin America (colored shading) and number of antigenic variants of bat rabies reported (gray bars).

publications and rabies $\mathrm{AgV}$ by country $(r=0.775, \mathrm{df}=7, p=0.0142)$, as well as an association between the number of publications and the number of bat species rabies-positive by country $(r=0.883, \mathrm{df}=7, p=0.001)$.

In terms of numbers of species known to be rabies-positive by family, significant effects of family were found $\left(X^{2}=24.29, p=0.001\right)$; the most consistently rabies-positive family was Vespertilionidae $64 \%$ (25 species), followed by Noctilionidae 50\% (one), Mormoopidae

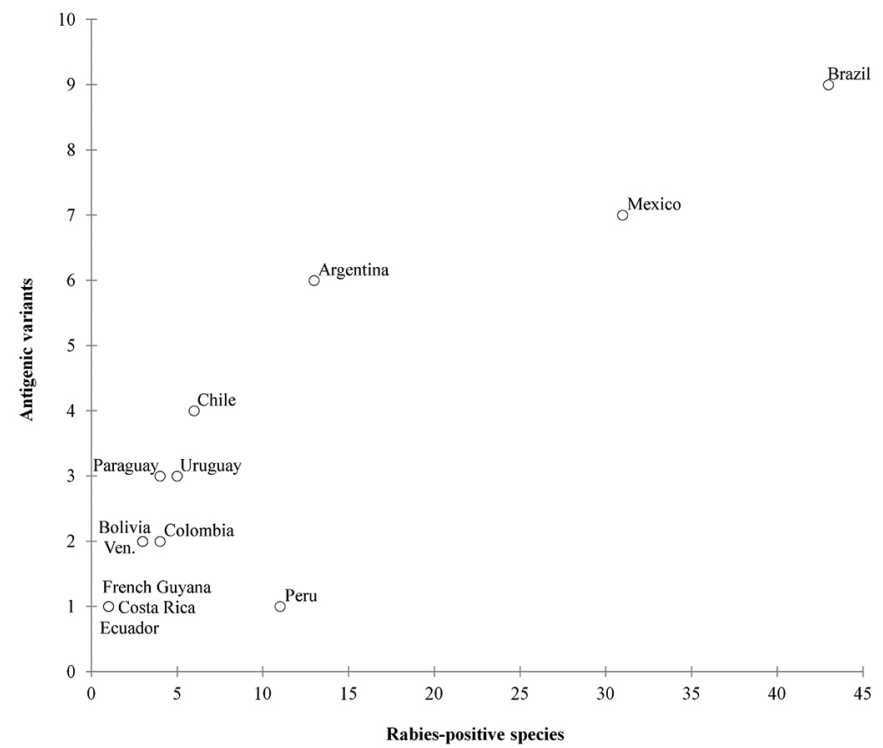

Fig. 3 - Numbers of rabies-positive species and antigenic variants of rabies reported by country (Table 1). Ven. = Venezuela.
44\% (four), Molossidae 42\% (16), Phyllostomidae with 17\% (29), and Emballonuridae 5\% (one species; see Table 1). Considering diet type, significant effects of diet on rabies positivity were found $\left(X^{2}=23.29\right.$, $p=0.0002)$ : the highest proportions of species rabies-positive were hematophagous $100 \%$ (three), carnivorous $60 \%$ (three), insectivorous $27 \%$ (50), followed by nectarivorous $19 \%$ (five), frugivorous $13 \%$ (10 species), and omnivorous $11 \%$ (four).

Antigenic variants: Only $13(60 \%)$ countries with rabies-positive bats reported information on antigenic variants (Fig. 2; Table 1). Significant relationships were found between the number of rabies-positive species and the number of antigenic variants reported by countries $\left(r^{2}=0.83\right.$, $P<0.001$; Fig. 3). Brazil had the highest number of rabies-positive bat species (43 species), with nine antigenic variants; in contrast, Mexico had fewer rabies-positive bat species, but an impressive number (seven) of antigenic variants. Indeed, in Mexico, four variants are in vampire bats and three in non-hematophagous bats, primarily insectivores (Fig. 3). Chile is the Latin American country with the fewest bat species, but four viral variants are known (Fig. 3); this number is impressive in comparison with Argentina and Mexico, which are known to have six and seven variants, respectively, but with much greater bat diversity (Fig. 2). The most frequent variants reported by country were AgV3 (12 countries), found mainly in D. rotundus; AgV4 (six countries), in $T$. brasiliensis; and AgV6 (five countries), in Lasiurus spp.

Conservation of bats in Latin America: Only one species from the rabies-positive group had increasing populations (Eptesicus fuscus); most (90\%) rabies-positive species are considered as Least Concern (Fig. 4). Indeed, rabies-positive species are more likely to be classed as Least Concern when compared with species where rabies virus has not been detected $\left(X^{2}=41.13, p<0.001\right)$. Bat species rabies-positive in Latin American and the Caribbean include one endangered species (Leptonycteris nivalis), and three species (L. yerbabuenae, Eumops perotis, Mormoops megalophylla) that have decreasing populations ${ }^{36}$. According to IUCN (2012), information was insufficient to classify the conservation threat status for $44(13 \%)$ bat species reported in Latin America.
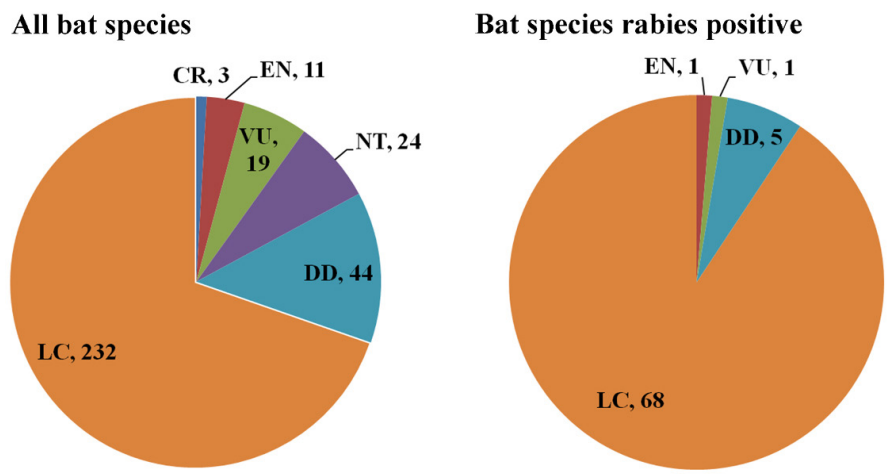

Fig. 4 - Conservation status for all bat species and rabies positive bat species in Latin America and the Caribbean. CR: Critically Endangered, EN: Endangered, VU: Vulnerable, NT: Near Threatened, LC: Least Concern, DD: Data Deficient.

\section{DISCUSSION}

Bat-borne rabies in Latin America and the Caribbean presents a complex and incompletely understood situation. Across the region, bats 
of all diet types have been found infected with rabies, but insectivorous bats include the highest number of rabies-positive species (184 species), but the lowest proportion of species diversity (27\%); for hematophagous and carnivorous species high proportions of rabies-positive species were found ( $100 \%$ and $60 \%$ respectively), but numbers of species for these diets were low. Because only three hematophagous bat species are known, and only three carnivorous species were reported as rabies-positive, results from these chi-square tests must be considered with caution, as the low numbers of observations may render the results unreliable. In light of frequent commensalism with humans, insectivorous bats present risk of rabies transmission to humans ${ }^{63}$, as in the case of the insectivorous bat $T$. brasiliensis, found abundantly in urban environments from Mexico to Argentina and Chile ${ }^{10,25,76,90}$.

Hematophagous bats include only three species, but a significant role in numerous rabies outbreaks in humans and livestock has been attributed to D. rotundus populations, possibly in light of their ecological plasticity and wide geographic distribution ${ }^{47}$. The diet and cryptic behavior of vampire bats represent an overt source of human and animal bite contact, compared to other bat diet types ${ }^{88}$. Viral characterization using monoclonal antibodies gives clues about the mammal reservoir involved ${ }^{4,21,69}$, but, considering the high diversity of viral lineages in Latin America, molecular genetic tools are often used for confirmation $25,32,67,69,90,92$. The number of bat species rabiespositive and rabies $\mathrm{AgV}$ by country appear to be linked to research effort, but not to bat species richness by country. More antigenic variants were reported in countries where more bat species rabies-positive are found (Fig. 3 ). This close association between amount of rabies-positive species and number of antigenic variants is strong evidence that more lineages could be found if countries with high bat biodiversity increase research effort. For example, a report was found of $T$. brasiliensis as rabies-positive for Dominican Republic, but no reports were found for Haiti, even though the two countries share a single island ${ }^{62}$.

However, substantial gaps exist in the knowledge of bat-rabies ecology, such as how the virus spreads among populations ${ }^{86}$. Seasonal migrations of species of bats in the genus Lasiurus may link to the spread of rabies virus over thousands of kilometers along migration routes ${ }^{43}$. Nevertheless, rabies virus variants linked to this genus have not been reported in all Latin American and Caribbean countries where the species is present. Geographic origins of rabies in the Americas remain unclear, but recent evidence indicates that vampire strains may not be the source of bat-borne rabies in the Americas ${ }^{46}$.

Antigenic variants differ among bat species and geographic locations. For instance, T. brasiliensis is widely distributed in Latin America, and across its distribution, diverse rabies antigenic variants have been reported $^{44}$. In Mexico, T. brasiliensis is the main reservoir of $\mathrm{AgV9}$, but in South America the same species carries AgV4 ${ }^{89}$. Lasiurus spp., on the other hand, carry AgV6 across their broad geographic distribution ${ }^{43}$, although with some exceptions ${ }^{26}$ and rabies lineages from other bat species have been found in Lasiurus genus, suggesting cross-species transmission ${ }^{70,93}$, contrasting with a report from North America, where Lasiurus are more likely to be donors than recipients of spillover ${ }^{83}$. These differences in the distribution of virus variants may result from geographic isolation and host behavior ${ }^{55}$, showing the complex dynamics of rabies in bat populations ${ }^{90}$. Bat rabies antigenic variants have also been found in skunks (Mephitis mephitis) and gray foxes (Urocyon cinereoargenteus) of North America, demonstrating successful bat-borne rabies host shift events to novel host species with viral persistence and adaptation for transmission ${ }^{45,48}$. In Latin America, bat-borne antigenic variants of rabies have been found in domestic carnivores (dogs and cats) in Mexico, Costa Rica, Colombia, Brazil, Argentina, and Chile $4,65,69,76,90,92$. Bat rabies outbreaks have been associated with habitat disturbance and ecosystem alteration ${ }^{44}$, with some historic and current evidence in Latin America ${ }^{5,14,32,49,51,56,77}$; a recent key article highlighted the need to understand how anthropogenic perturbation triggers outbreaks of batborne diseases ${ }^{34}$, and this phenomenon demands deeper study.

The rabies literature presently focuses largely on disease diagnosis and detection of rabies; few studies have sought to understand host-virus dynamics or the ecology of these interactions ${ }^{18,28,83-85}$. An understanding of virus and host ecology is fundamental, however, to preventing outbreaks in humans and animals. Indeed, a series of significant research gaps, were found as follows: 1) Relatively few countries report antigenic variant identifications. As a result, virus variant distributions are poorly characterized geographically. To date, the most relevant and complete phylogenetic studies of bat-borne rabies have not included spatial analyses ${ }^{11,83}$; detailed geographic and environmental characterization of bat rabies could enhance future phylogeographic research. Better characterization of rabies lineages in Latin America brings the opportunity to identify bat-borne rabies in humans and understand how climate is linked to rabies lineage distributions in the Americas. STREICKER et al. (2012b), found effects of climate on viral evolution of bat rabies across temperate and tropical regions, although more detailed analysis is needed for tropical lineages. 2) Little is known about the ecology of rabies-bat dynamics. In Latin America, few ecological studies have been undertaken regarding rabies persistence mechanisms (but see BLACKWOOD et al., 2013); further research should focus on longitudinal serologic studies to understand temporal and spatial infection dynamics of rabies in bat populations ${ }^{30,34}$. 3) Bat species carrying rabies are not reported in all countries: such epidemiological gaps delay human rabies diagnosis and prevention ${ }^{4}$. 4) Latin American bat species population status is frequently poorly known. Understanding of bat population dynamics is indispensable in comprehending the ecology of this and other infectious diseases $^{34}$. Finally, 5) effects of habitat fragmentation on virus occurrence in bats and transmission to humans are poorly studied: although land-use change has been suggested as related to rabies outbreaks, no scientific quantification of this phenomenon exists ${ }^{34}$.

Density of mammals in human settlements (mainly cats and dogs) may prove more important than just bat presence in determining transmission risk of non-hematophagous bat rabies to people $e^{4,22,45,65,66,68,92}$, in view of low prevalence in bat colonies ${ }^{24}$. Considering that bats are natural rabies hosts, an integrated approach should seek equilibrium among public health, agriculture, and biodiversity conservation interests. Public health agencies should include bat ecologists in their teams, to understand bat population dynamics for rabies prevention ${ }^{34}$; unfortunately, such links are still missing. A strategic opportunity to reduce the gap between ecology and public health is the Red Latinoamericana para la Conservación de Murciélagos (Latin American Network for Bat Conservation; www. relcomlatinoamerica.net). On the other hand, present laboratory-based rabies surveillance in Latin America has been advancing programs to eliminate dog rabies, a valuable source of data for bat-borne rabies studies $^{34}$. Finally, bat conservation has become a significant concern in recent years ${ }^{72}$, but an important number of species in the region are deficient in data to ascertain their conservation status. 


\section{RESUMEN}

\section{Rabia transmitida por murciélagos en Latino América}

La situación de rabia en América es compleja: la rabia en perros ha disminuido drásticamente pero los murciélagos están siendo reconocidos cada vez más como reservorios naturales de otras variantes de rabia. Aquí compilamos las especies de murciélagos reconocidas como positivas a rabia con diferentes variantes antigénicas, así como su relación con el estado de conservación de los murciélagos a lo largo de América Latina. El virus de rabia está ampliamente distribuido en las especies de murciélagos de América Latina, 22.5\% (75) de las especies de murciélagos conocidas han sido confirmadas como especies positivas a rabia. La mayoría de las especies de murciélagos reportadas como positivas a rabia son clasificadas por la Unión Internacional para la Conservación de la Naturaleza como "Preocupación Menor". De acuerdo al tipo de dieta, los murciélagos insectívoros tuvieron la mayor cantidad de especies reconocidas como reservorio del virus rabia, mientras en proporción los hematófagos fueron los más importantes. Investigaciones a escala gruesa deben buscar entender aspectos de ecología de la rabia; es necesaria la información básica sobre la distribución y dinámica poblacional para muchas especies de murciélagos de América Latina y el Caribe; y el efecto del cambio del paisaje en la generación de brotes de rabia transmitida por murciélagos permanece sin ser evaluado. Por último, para entender y prevenir enfermedades emergentes a partir de los murciélagos es necesario un enfoque integral incluyendo salud pública, ecología y biología de la conservación.

\section{ACKNOWLEDGMENTS}

Special thanks to the Programa para la Conservación de los Murciélagos de Chile (PCMCH) for promoting the development of this review, and Emma Stapleton who donated the ArcGIS license. Thanks also to Ruben Barquéz, who reviewed an earlier version of this manuscript, and to Valeska Rodriguez for assistance in data compilation. Universidad Andres Bello provided the grant DI-412-13/I. LEE is student in the Conservation Medicine Program at the Universidad Andres Bello, this manuscript is part of the fulfillment of his $\mathrm{PhD}$ degree.

\section{REFERENCES}

1. Acha P. Epidemiología de la rabia bovina paralítica transmitida por los quirópteros. Bol Oficina Sanit Panam. 1968;64:411-30.

2. Aguilar-Setién A, Campos YL, Cruz ET, Kretschner R, Brochier B, Pastoret P. Vaccination of vampire bats using recombinant vaccinia-rabies virus. J Wildl Dis. 2002;38:539-44.

3. Arellano-Sota C. Control of bovine paralytic rabies in Latin America and the Caribbean. World Anim Rev. 1993;76:19-26.

4. Badilla X, Pérez-Herra V, Quirós L, Morice A, Jiménez E, Sáenz E, et al. Human rabies: a reemerging disease in Costa Rica? Emerg Infect Dis. 2003;9:721-3.

5. Batista-da-Costa M, Bonito R, Nishioka SA. An outbreak of vampire bat bite in Brazilian village. Trop Med Parasitol. 1993;44:219-20.

6. Blackwood JC, Streicker DG, Altizer S, Rohani P. Resolving the roles of immunity, pathogenesis, and immigration for rabies persistence in vampire bats. Proc Natl Acad Sci USA. 2013;110(51): 20837-42.
7. Carneiro V. Transmission of rabies by bats in Latin America. Bull World Health Organ. $1954 ; 10: 775-80$

8. Carrera N, Quevedo N, Urbieta S, San Miguel M, Irala L. Rabia en murciélagos frugívoros e insectívoros, Villa Florida, Misiones, Paraguay 2006. Rev Inst Med Trop (Asunción, Paraguay). 2008;3:7-14.

9. Childs JE, Real LA. Epidemiology. In: Jackson AC, Wunner WH, editors. Rabies. $2^{\text {nd }}$ ed. Burlington: Elsevier; 2007. p. 123-99.

10. Cisterna D, Bonaventura R, Caillou S, Pozo O, Andreau ML, Fontana LD, et al. Antigenic and molecular characterization of rabies virus in Argentina. Virus Res. 2005;109:13947.

11. Condori-Condori RE, Streicker DG, Cabezas-Sanchez C, Velasco-Villa A. Enzootic and epizootic rabies associated with vampire bats, Peru. Emerg Infect Dis. 2013;19:14639.

12. Constantine DG. Bat rabies and other Lyssavirus infections. In: Blehert D, editor. Reston, Virginia: U.S. Geological Survey; 2009. p. 68.

13. Courter RD. Bat rabies. Public Health Rep. 1954;69:9-16.

14. Da Rosa ES, Kotait I, Barbosa TF, Carrieri ML, Brandão PE, Pinheiro AS, et al. Bat-transmitted human rabies outbreaks, Brazilian Amazon. Emerg Infect Dis. 2006;12:1197-202.

15. Delpietro HA, Lord RD, Russo RG, Gury-Dhomen F. Observations of sylvatic rabies in Northern Argentina during outbreaks of paralytic cattle rabies transmitted by vampire bats (Desmodus rotundus). J Wildl Dis. 2009;45:1169-73.

16. De Mattos CA, De Mattos CC, Smith JS, Miller ET, Papo S, Utrera A, et al. Genetic characterization of rabies field isolates from Venezuela. J Clin Microbiol. 1996;34:1553-8

17. De Mattos CC, De Mattos CA, Loza-Rubio E, Aguilar-Setién A, Orciari LA, Smith JS. Molecular characterization of rabies virus isolates from Mexico: implications for transmission dynamics and human risk. Am J Trop Med Hyg. 1999;61:587-97.

18. Dimitrov DT, Hallam TG, Rupprecht CE, McCracken GF. Adaptive modeling of viral diseases in bats with a focus on rabies. J Theor Biol. 2008;255:69-80.

19. Ellison JA, Johnson SR, Kuzmina N, Gilbert A, Carson WC, VerCauteren KC, et al. Multidisciplinary approach to epizootiology and pathogenesis of bat rabies viruses in the United States. Zoonoses Public Health. 2013;60:46-57.

20. Favi M, Yung V, Pavletic C, Ramirez V, De Mattos C, De Mattos CA, et al. Rol de los murciélagos insectívoros en la transmisión de la rabia en Chile. Arch Med Vet. 1999;31:157-65.

21. Favi M, De Mattos C, Yung V, Chala E, López LR, De Mattos CC. First case of human rabies in Chile caused by an insectivorous bat virus variant. Emerg Infect Dis. 2002;8:79-81.

22. Favi M, Nina A, Yung V, Fernández J. Characterization of rabies virus isolates in Bolivia. Virus Res. 2003;97:135-40.

23. Favi M. Rabia en murciélagos de Chile. In: Canals M, Cattan P, editors. Radiografía a los murcielagos de Chile. Santiago de Chile: Editorial Universitaria; 2008. p. 91-6.

24. Favi M, Rodríguez L, Espinosa MC, Yung V. Rabies in Chile: 1989-2005. Rev Chilena Infectol. 2008;25:S8-13.

25. Favi M, Bassaletti A, López DJ, Rodríguez AL, Yung PV. Descripción epidemiológica del reservorio de rabia en murciélagos de la Región Metropolitana, Chile 2000-2009. Rev Chilena Infectol. 2011;28:223-8. 
26. Favoretto SR, Carrieri ML, Cunha EM, Aguiar E, Silva LH, Sodre MM, et al. Antigenic typing of Brazilian rabies virus samples isolated from animals and humans, 19892000. Rev Inst Med Trop Sao Paulo. 2002;44:91-5.

27. Galera Castilho J, Carnieli Jr P, Durymanova EA, De Oliveira Fahl W, De Novaes Oliveira R, Macedo CI, et al. Human rabies transmitted by vampire bats: antigenic and genetic characterization of rabies virus isolates from the Amazon region (Brazil and Ecuador). Virus Res. 2010;153:100-5.

28. George DB, Webb CT, Farnsworth ML, O'Shea TJ, Bowen RA, Smith DL, et al. Host and viral ecology determine bat rabies seasonality and maintenance. Proc Natl Acad Sci USA. 2011;108:10208-13

29. Gibbons RV. Cryptogenic rabies, bats, and the question of aerosol transmission. Ann Emerg Med. 2002;39:528-36.

30. Gilbert AT, Fooks AR, Hayman DT, Horton DL, Müller T, Plowright R, et al. Deciphering serology to understand the ecology of infectious diseases in wildlife. EcoHealth. 2013;10:298-313.

31. Goodwin GG, Greenhall A. A review of the bats of Trinidad and Tobago: descriptions, rabies infection, and ecology. Bull Am Mus Nat Hist. 1961;122:187-302.

32. Guarino H, Castilho JG, Souto J, Oliveira R de N, Carrieri ML, Kotait I. Antigenic and genetic characterization of rabies virus isolates from Uruguay. Virus Res. 2013;173:415-20.

33. Gury-Dohmen F, Beltrán F. Aislamiento de virus rábico en glándulas salivales de murciélagos insectívoros. Rev Sci Tech. 2009;28:987-93.

34. Hayman DT, Bowen RA, Cryan PM, McCracken GF, O’Shea TJ, Peel AJ, et al. Ecology of zoonotic infectious diseases in bats: current knowledge and future directions. Zoonoses Public Health. 2013;60:2-21.

35. Hirano S, Itou T, Carvalho AA, Ito FH, Sakai T. Epidemiology of vampire bat-transmitted rabies virus in Goiás, central Brazil: re-evaluation based on G-L intergenic region. BMC Res Notes. 2010;3:288.

36. International Union for Conservation of Nature. IUCN Red List of threatened species. Version 2012.2 [Internet]. 2012. Available from: http://www.iucnredlist.org/

37. Knobel DL, Cleaveland S, Coleman PG, Fèvre EM, Meltzer MI, Miranda MEG, et al Re-evaluating the burden of rabies in Africa and Asia. Bull World Health Organ. 2005;83:360-8.

38. Kobayashi Y, Sato G, Kato M, Itou T, Cunha EMS, Silva MV, et al. Genetic diversity of bat rabies viruses in Brazil. Arch Virol. 2007;152:1995-2004.

39. Kunz TH. Feeding ecology of a temperate insectivorous bat (Myotis velifer). Ecology. 1974;55:693-711.

40. Kunz TH, Whitaker JO Jr. An evaluation of fecal analysis for determining food habits of insectivorous bats. Can J Zool. 1983;61:1317-21.

41. Kunz TH, Pierson E. Bats of the world: an introduction. In: Nowak R, editor. Walker's bats of the world. Baltimore: Johns Hopkins University Press; 1994. p. 1-46.

42. Kunz TH, Braun De Torrez E, Bauer D, Lobova T, Fleming TH. Ecosystem services provided by bats. Ann NY Acad Sci. 2011;1223:1-38.

43. Kuzmin IV, Rupprecht CE. Bat rabies. In: Jackson AC, Wunner WH, editors. Rabies. $2^{\text {nd }}$ ed. Baltimore: Elsevier; 2007. p. 259-307.

44. Kuzmin IV, Bozick B, Guagliardo S, Kunkel R, Shak JR, Tong S, et al. Bats, emerging infectious diseases, and the rabies paradigm revisited. Emerg Health Threats J. 2011;4:1-17.
45. Kuzmin IV, Shi M, Orciari LA, Yager PA, Velasco-Villa A, Kuzmina N, et al. Molecular inferences suggest multiple host shifts of rabies viruses from bats to mesocarnivores in Arizona during 2001-2009. PLOS Pathog. 2012;8:e1002786.

46. Kuzmina NA, Kuzmin IV, Ellison JA, Taylor ST, Bergman DL, Dew B, et al. A reassessment of the evolutionary timescale of bat rabies viruses based upon glycoprotein gene sequences. Virus Genes. 2013;47:305-10.

47. Lee DN, Papeş M, Van Den Bussche RA. Present and potential future distribution of common vampire bats in the Americas and the associated risk to cattle. PLOS One 2012;7:e42466.

48. Leslie MJ, Messenger S, Rohde RE, Smith J, Cheshier R, Hanlon C, et al. Bat-associated rabies virus in skunks. Emerg Infect Dis. 2006;12:1274-7.

49. López A, Miranda P, Tejada E, Fishbein DB. Outbreak of human rabies in the Peruvian jungle. Lancet. 1992;339:408-11.

50. Loza-Rubio E, Rojas-Anaya E, Banda-Ruíz VM, Nadin-Davis SA, Cortez-García B Detection of multiple strains of rabies virus RNA using primers designed to target Mexican vampire bat variants. Epidemiol Infect. 2005;133:927-34.

51. McCarthy TJ. Human depredation by vampire bats (Desmodus rotundus) following a hog cholera campaign. Am J Trop Med Hyg. 1989;40:320-2.

52. Meynard J-B, Flamand C, Dupuy C, Mahamat A, Eltges F, Queuche F, et al. First human rabies case in French Guiana, 2008: epidemiological investigation and control. PLOS Negl Trop Dis. 2012;6:e1537.

53. Morales Alarcón A. Referencia: Badillo R, Mantilla JC, Pradilla G. Encefalitis rábica humana por mordedura de murciélago en un área urbana de Colombia. Biomédica. 2009;29:191-203.

54. Nadin-Davis SA, Torres G, Ribas M, Gúzman M, Crúz De La Paz R, Morales M, et al. A molecular epidemiological study of rabies in Cuba. Epidemiol Infect. 2006;134:131324.

55. Nadin-Davis SA. Molecular epidemiology. In: Jackson AC, Wunner WH, editors. Rabies. $2^{\text {nd }}$ ed. London: Elsevier; 2007. p. 69-122.

56. Nehuaul BB, Dyrting AE. An outbreak of rabies in man in British Guiana. Am J Trop Med Hyg. 1965;14:295-6.

57. Organización Panamericana de la Salud. Vigilancia epidemiológica de la rabia en las Americas. Rio de Janeiro: PANAFTOSA-OPS/OMS; 2000. p. 40.

58. Organización Panamericana de la Salud. Vigilancia epidemiológica de la rabia en las Americas. Rio de Janeiro: PANAFTOSA-OPS/OMS; 2001. p. 42

59. Organización Panamericana de la Salud. Vigilancia epidemiológica de la rabia en las Americas. Rio de Janeiro: PANAFTOSA-OPS/OMS; 2002. p. 39.

60. Organización Panamericana de la Salud. Vigilancia epidemiológica de la rabia en las Americas. Rio de Janeiro: PANAFTOSA-OPS/OMS; 2003. p. 40.

61. Organización Panamericana de la Salud. Vigilancia epidemiológica de la rabia en las Americas. Rio de Janeiro: PANAFTOSA-OPS/OMS; 2004. p. 40.

62. Organización Panamericana de la Salud. República Dominicana: elimination of dogtransmitted rabies in Latin America: situation analysis. Washington: OPS; 2004. p. $58-9$

63. Organización Panamericana de la Salud. Plan de acción para la prevención y el control de la rabia en las Américas 2005-2009. Rio de Janeiro: PANAFTOSA-OPS/OMS; 2007. p. $1-28$. 
64. Organización Panamericana de la Salud. Paraguay: conclusiones de la REDIPRA 13 para evitar la rabia en las Américas. XIII Reunión de Directores de los Programas Nacionales de Control de la Rabia en América Latina. Buenos Aires, Argentina; 2010. p. 6-7.

65. Páez A, Núñez C, García C, Bóshell J. Molecular epidemiology of rabies epizootics in Colombia: evidence for human and dog rabies associated with bats. J Gen Virol. 2003;84:795-802.

66. Páez A, Saad C, Núñez C, Bóshell J, Nuñez C, Boshell J. Molecular epidemiology of rabies in northern Colombia 1994-2003. Evidence for human and fox rabies associated with dogs. Epidemiol Infect. 2005;133:529-36.

67. Páez A, Velasco-Villa A, Rey G, Rupprecht CE. Molecular epidemiology of rabies in Colombia 1994-2005 based on partial nucleoprotein gene sequences. Virus Res. 2007; $130: 172-81$

68. Páez A, Polo L, Heredia D, Nuñez C, Rodriguez M, Agudelo C, et al. Brote de rabia humana transmitida por gato en el municipio de Santander de Quilichao, Colombia, 2008. Rev Salud Publica (Bogota). 2009;11:931-43.

69. Piñero C, Gury Dohmen F, Beltran F, Martínez L, Novaro L, Russo S, et al. High diversity of rabies viruses associated with insectivorous bats in Argentina: presence of several independent enzootics. PLOS Negl Trop Dis. 2012;6:e1635.

70. Queiroz LH, Favoretto SR, Cunha EM, Campos AC, Lopes MC, De Carvalho C, et al. Rabies in southeast Brazil: a change in the epidemiological pattern. Arch Virol. 2012;157:93-105.

71. R Core Team. R: a language and environment for statistical computing [Internet]. Vienna: R Foundation for Statistical Computing; 2012. Available from: http://www.r-project. org

72. Racey PA, Hutson AM, Lina PHC. Bat rabies, public health and European bat conservation. Zoonoses Public Health. 2013;60:58-68.

73. Rupprecht CE, Hanlon CA, Hemachudha T. Rabies re-examined. Lancet Infect Dis. $2002 ; 2: 327-43$

74. Rupprecht CE. Bats, emerging diseases, and the human interface. PLOS Negl Trop Dis. 2009;3:e451.

75. Salmón-Mulanovich G, Vásquez A, Albújar C, Guevara C, Laguna-Torres VA, Salazar M, et al. Human rabies and rabies in vampire and nonvampire bat species, Southeastern Peru, 2007. Emerg Infect Dis. 2009;15:1308-10.

76. Schaefer R, Batista HB, Franco AC, Rijsewijk FA, Roehe PM. Studies on antigenic and genomic properties of Brazilian rabies virus isolates. Vet Microbiol. 2005;107:161-70.

77. Schneider MC, Aron J, Santos-Burgoa C, Uieda W, Ruiz-Velazco S. Common vampire bat attacks on humans in a village of the Amazon region of Brazil. Cad Saude Publica. 2001;17:1531-6.

78. Schneider MC, Belotto A, Adé MP, Leanes L, Correa E, Tamayo H, et al. Epidemiologic situation of human rabies in Latin America in 2004. Epidemiol Bull. 2005;26:2-4.
79. Schneider MC, Belotto A, Adé MP, Hendrickx S, Leanes LF, Rodrigues MJ de F, et al. Current status of human rabies transmitted by dogs in Latin America. Cad Saude Publica. 2007;23:2049-63.

80. Schneider MC, Romijn P, Uieda W, Tamayo H, Silva D, Belotto A, et al. Rabies transmitted by vampire bats to humans: an emerging zoonotic disease in Latin America? Rev Panam Salud Publica. 2009;25:260-9.

81. Sheeler-Gordon LL, Smith JS. Survey of bat populations from Mexico and Paraguay for rabies. J Wildl Dis. 2001;37:582-93.

82. Sodré MM, Gama AR, Almeida MF. Updated list of bat species positive for rabies in Brazil. Rev Inst Med Trop Sao Paulo. 2010;52:75-81.

83. Streicker DG, Turmelle AS, Vonhof MJ, Kuzmin IV, McCracken GF, Rupprecht CE. Hos phylogeny constrains cross-species emergence and establishment of rabies virus in bats. Science. 2010;329:676-9.

84. Streicker DG, Altizer SM, Velasco-Villa A, Rupprecht CE. Variable evolutionary route to host establishment across repeated rabies virus host shifts among bats. Proc Natl Acad Sci USA. 2012a;109:19715-20.

85. Streicker DG, Lemey P, Velasco-Villa A, Rupprecht CE. Rates of viral evolution are linked to host geography in bat rabies. PLOS Pathog. 2012b;8:e1002720.

86. Streicker DG, Recuenco S, Valderrama W, Gómez Benavides J, Vargas I, Pacheco V, et al Ecological and anthropogenic drivers of rabies exposure in vampire bats: implications for transmission and control. Proc R Soc London B. 2012c;279:3384-92.

87. Turmelle AS, Jackson FR, Green D, McCracken GF, Rupprecht CE. Host immunity to repeated rabies virus infection in big brown bats. J Gen Virol. 2010;91:2360-6.

88. Valderrama J, García I, Figueroa G, Rico E, Sanabria J, Rocha N, et al. Brotes de rabia humana transmitida por vampiros en los municipios de Bajo y Alto Baudó, departamento del Chocó, Colombia 2004-2005. Biomedica. 2006;26:387-96.

89. Velasco-Villa A, Gómez-Sierra M, Hernández-Rodriguez G, Juárez-Islas V, MeléndezFelix A, Vargas-Pino F, et al. Antigenic diversity and distribution of rabies virus in Mexico. J Clin Microbiol. 2002;40:951-8.

90. Velasco-Villa A, Orciari LA, Juárez-Islas V, Gómez-Sierra M, Padilla-Medina I, Flisser A, et al. Molecular diversity of rabies viruses associated with bats in Mexico and other countries of the Americas. J Clin Microbiol. 2006;44:1697-710.

91. Warner CK, Zaki SR, Shieh W, Whitfield SG, Smith JS, Orciari LA, et al. Laboratory investigation of human deaths from vampire bat rabies in Peru. Am J Trop Med Hyg. 1999;60:502-7.

92. Yung V, Favi M, Fernández J. Genetic and antigenic typing of rabies virus in Chile. Arch Virol. 2002;147:2197-205.

93. Yung V, Favi M, Fernández J. Typing of the rabies virus in Chile, 2002-2008. Epidemiol Infect. 2012;140:2157-62.

Received: 2 August 2013

Accepted: 9 May 2014 